the most active substance found being $\alpha x$-tetra- $n$ amyldiamino- $n$-decane, which, however, proved not to be of clinical value.

Sir Gilbert Morgan then gave an account of work done on homologous series of derivatives of $\gamma$-aminophenylarsonic acids of the general formula $(\mathrm{HO})_{2} \cdot \mathrm{AsO} \cdot \mathrm{C}_{6} \mathrm{H}_{4} \cdot \mathrm{NH} \cdot \mathrm{CO}\left(\mathrm{CH}_{2}\right)_{n} \cdot \mathrm{CO} \cdot \mathrm{N} R_{1} R_{2}$, which may be regarded as combining the desirable features of the well-known arsenical drugs, acetyl$p$-arsanilic acid and tryparsone, $(\mathrm{NaO})(\mathrm{OH})$. $\mathrm{AsO} \cdot \mathrm{C}_{6} \mathrm{H}_{4} \cdot \mathrm{NH} \cdot \mathrm{CH}_{2} \cdot \mathrm{CONH}_{2}$, the latter being probably the most widely used drug of this type for the treatment of sleeping sickness and late syphilis. Among the new drugs, sodium succinanilomethylamide- $p$-arsonate $\left(n=2 ; \quad R_{1}=\mathrm{H}\right.$; $R_{2}=\mathrm{CH}_{3}$ ) has been selected and has already given promising results in clinical trials in sleeping sickness in Nigeria. In connexion with the same investigation, Dr. E. Walton directed attention to the low toxicity of this type of arsenical compound, and showed that trypanocidal action is enhanced by an amide-group in the $p$-position in phenylarsonic acid 4 .

The next two contributions dealt with the new streptococcicidal drugs, of which the first example was Domagk's 2 : 4-diaminoazobenzene-4'-sulphonamide ${ }^{5}$, which was speedily shown, as the result of work in France and in Great Britain, to be replaceable by the simpler substance $p$-aminobenzenesulphonamide (sulphanilamide), which is already in use on a large scale. Mr. W. H. Gray stated that the results of numerous attempts to improve upon this simple substance indicated that both the sulphur atom and the amino-group are essential, that duplication of either on the same nucleus destroys activity, which is also the effect of additional substituents. A more active but more toxic substance is $4: 4^{\prime}$-diaminodiphenylsulphone, in which activity also disappears on elimination of either the sulphone or the aminogroups. Dealing with biological work on these drugs, Dr. G. A. H. Buttle said that sulphanilamide will cure mice infected with 10,000 times the lethal dose of streptococci. As tested on mice, the drug appears to have some action in all bacterial infections characterized by rapid multiplication of the invading bacterium, but it fails in infections where a small number of organisms can produce a sufficiently potent toxin to kill the animal, as in diphtheria. As regards the mode of action, there is experimental evidence for the view that by some means still unknown the drug delays the growth of the organisms or affects them in such a manner as to facilitate their destruction by the leucocytes of the blood ${ }^{6}$.

Returning to anti-malarial drugs, Dr. H. King described work done in collaboration with Dr. Cohen and Dr. Ainley on two substances based on the structure of quinine, details of which will be published shortly.

Dr. W. H. Linnell showed that although there are a number of useful acridine derivatives in use in medicine as bactericides and amœbicides, the possibilities of this heterocyclic nucleus have not been fully explored, and in his recent survey ${ }^{2}$ of monoamino- and diamino-acridines, he has found that 1-aminoacridines are not bactericidal, that an amino-group in position 3 lowers toxicity and that 3 : 8-diaminoacridine is as active as, but much less toxic than, the well-known $2: 8$-diaminoacridine (proflavine).

\footnotetext{
1 Schmidt, $Z$, angew, Chem, 43, 963 (1930). Gray and Trevan, Trans. Roy. Soc. Trop. Med. Hyg., 25, 147 (1931).

See, for example, van Dongen and Sanches, Arch, intern. Pharmacodyn., 55, 52 (1937).

3 Butler, Hostler and Cretcher, J. Amer. Chem. Soc., 59, 2354 (1937).

4 Morgan and Walton, Chem. and Ind., 56, 853 (1937).

- Domagk, Deut. med. Woch., 61, 250 (1935).

- Gray, Buttle and Stephenson, Biochem. J., 31, 724 (1937).

- Albert and Linnell, J. Chem. Soc., 88, 1614 (1936) ; also a further paper in the Press.
}

\title{
The Quatercentenary of the University of Coimbra
}

$\mathrm{T}^{\mathrm{H}}$ HE beautiful old city of Coimbra, the ancient capital of the kingdom of Portugal from the time of King Afonso Henriques to that of King Afonso III, rises picturesquely from the banks of the Mondego River and is crowned by the historic buildings of its university. The first centre of higher learning in Portugal, the first "Estudo geral", was established at Lisbon in March 1290 by King Diniz, but was later brought to the capital at Coimbra (in 1308). Twice transferred back in the fourteenth century (1338 and 1377) to the banks of the Tagus, the University was finally established at Coimbra in 1537 by King John III, who had undertaken a great reform of university studies. These reforms culminated in the reign of King José I, when in the last quarter of the eighteenth century his famous Prime Minister, the Marqués de Pombal, greatly transformed and modernized the work of the University, introducing especially the study of natural science.

The four hundredth anniversary of the final establishment of the University at Coimbra in 1537 was celebrated during the days December 6-10 by a series of fine ceremonies and much 
splendid hospitality. Many men of letters and science had come from various parts of the world to do honour to the famous University, and were entertained in a most lavish manner by the Government of Portugal, the University authorities, and the City of Coimbra.

The British guests who had come specially to Portugal for the quatercentenary were Prof. F. G. Donnan (chemistry, University of London and the Royal Society) and Miss Jane Donnan, Prof. W. J. Entwistle (Spanish and Portuguese, University of Oxford), Mr. J. Ramsbottom (keeper of botany, British Museum (Natural History) ), Prof. W. F. Starkie (Spanish and Italian, Trinity College, Dublin) and Prof. W. M. Thornton (electrical engineering, Universities of Durham, Birmingham, Reading and Bristol). The British Embassy in Lisbon was represented by the chargé d'affaires, Mr. Bateman, and the secretary, Mr. Gorell-Barnes (who also represented the University of Cambridge), whilst Mr. Dible, British Consul in Oporto, represented the consular service. Notable amongst those who represented the British colony in Lisbon were Mr. R. G. Jayne, head of the well-known shipping firm of Garland, Laidley and Co., and the Rev. Stewart Robertson (who also represented the University of Edinburgh) and Mrs. Robertson.

The celebrations began in the afternoon of December 6 with a general assembly in the "Patio" of the University, followed by addresses of welcome and a reception in the splendid official apartments of the distinguished Rector of the University, Dr. João Duarte de Oliveira.

During the forenoon of December 7 an exhibition of books was opened in the general Library of the University. This building, constructed between 1717 and 1725 on the initiative of the Rector, Nuno da Silva Teles, is a magnificent example of the Portuguese baroque style of the period of King John V, and contains a vast store of valuable manuscripts and books. There was also opened at the same time a most interesting display of early documents in the archives of the University.

At noon came addresses of welcome by the City Council and a reception in the University; the President of the Republic, his Excellency General Oscar de Fragoso Carmona, had intended to be present, but he was prevented from doing so by indisposition.

Most of the afternoon of December 7 was dedicated to a solemn session in the famous "Sala dos Capêlos" of the University. This noble hall was the work of the Rector, Manuel de Saldanha, who in 1654 decided to transform and embellish the great salon of the Royal Palace which at that time served for the ceremonies of the University. It possesses a fine dado of the beautiful "azulejos", that is, painted and glazed tiles, for which Portugal is so famous, and a splendid domed ceiling of painted panels, whilst its walls are adorned by portraits of the kings and queens of Portugal. Addresses were delivered by the Rector and the Minister of Education, Dr. Antonio Faria Carneiro Pacheco, and Prof Damião Peres gave an eloquent account of the University of Coimbra in the history of Portuguese culture. Then short speeches of congratulation were made by members of the various foreign delegations, Prof. Entwistle speaking in Portuguese on behalf of the representatives of Great Britain.

The afternoon of December 7 concluded with the inauguration of the "Sala do Brasil" in the Faculty of Letters. In the evening a splendid gala dinner was given in the University, at which were present the diplomatic corps and the senior delegates of the various nations. This was followed by a concert given by the symphony orchestra of the national broadcasting station. The Prime Minister, his Excellency Dr. Antonio de Oliveira Salazar, was able to be present during a part of these festivities.

At 11 o'clock on the morning of December 8, High Mass was celebrated by his Eminence the Cardinal Patriarch of Portugal, whilst during the afternoon in the Sala dos Capêlos, Senhor Mario Brandão was admitted to the degree of doctor, and honorary doctorates were conferred on a number of the foreign delegates, including Prof. Donnan and Mr. Ramsbottom. This was a scene never to be forgotten by the visitors. Round the great hall sat the diplomatic corps and the professors of the various faculties, the latter clad in their black gowns and silken "capelos" (differing in colour for each faculty) and wearing on their heads the wonderful "borlas" or academic hats. The body of the hall was filled with many ladies and guests of the University, whilst at the back surged an enthusiastic throng of students who gave Dr. Brandão and the honorary doctors a very hearty welcome. An extremely interesting feature of this ancient and historic ceremony was the embracing of the Rector Magnificus and the dean of the faculty by each honorary doctor in turn, whilst Dr. Brandão had the further privilege of being led round the stalls and the duty of embracing all the members of the faculties. One realized that this was a noble ceremony characteristic of the ancient brotherhood of learning, in which every new doctor was admitted to a special order and given a very friendly welcome by his elder brothers.

In the evening of December 8 a great banquet was given by the City Council in the hall of the splendid new High School named after King John III. At this banquet many students, all 
clad in their characteristic long black gowns, were present, so the proceedings were much enlivened by the gaiety and joy of youth. Various foreign delegates (including the present writer) were haled from the high table by groups of very pleasant fellows, given a student's gown, and conducted round the hall amidst cheers and rejoicing. One signed innumerable cards, drank much of the good wine of the country to the honour of Coimbra and Portugal, tried to speak bad Portuguese, and endeavoured to keep one's head and feet. It was evident that these good fellows, the representatives that night of the hope of the world, were admitting us to their comradeship and to the fellowship of the University of Coimbra. May God bless them !

On December 9 the programme included a football match and a torchlight procession of the students. Unfortunately, these events had to be cancelled owing to heavy rain. However, there was a very interesting concert of Portuguese music in the afternoon, given by the Philharmonic Orchestra of Lisbon, an evening meeting in the Avenida Theatre, and a gala ball in the great High School of King John III.

The celebrations closed on December 10 with a visit to the beautiful mountain resort of Buçaco and a lunch in the Palace Hotel. Thus terminated a visit to Coimbra and its famous University which will live in the memories of the British delegates as one of the pleasantest and most interesting events of their lives. The old city of Coimbra, crowned by its ancient University, and with its great Romanesque Cathedral of Sé Velha and its old church of Santa Cruz, in which lie buried King Afonso Henriques and King Sancho I, will ever remain with us a vivid and happy memory. We retain also a keen appreciation of the present as well as of the glorious past, and rejoice to have seen with our own eyes the great advances made in the University of Coimbra, as elsewhere in the land of our ancient and loyal allies, under the wise and beneficent leadership of President General Carmona and his great Prime Minister, Dr. Salazar. Dr. Salazar himself is a man of learning, one of the greatest, if not the greatest, of the sons of his Alma Mater, Coimbra. A distinguished professor of that University, destiny has led him to dedicate his pre-eminent abilities and virtues to the prosperity and happiness of the land of his birth. We who have experienced the splendid hospitality of his Government, and have had the privilege of witnessing the great and beneficent results of his wise and patriotic leadership of the Portuguese nation, unite wholeheartedly in wishing him and all our good friends of Portugal every prosperity and happiness in the future.

Before leaving Coimbra, I spent a very pleasant afternoon in the company of the professors of chemistry, Prof. Ruy Gustavo Couceiro da Costa and Prof. K. Coper. A remarkable experience was the visit to the Chemical Laboratory, a building in the neo-classical style erected in the last quarter of the eighteenth century during the reform period of the Marqués de Pombal (who approved and signed the architect's plan). How it would have rejoiced the heart of Lavoisier! Certainly the great Marquis must have been a man of remarkable foresight, and one cannot blame him or his architect for not having designed a building suitable to the requirements of 1937. Various interesting researches were in progress-a proof that good work can be done in buildings of great historical interest. Nevertheless, in case these lines should meet the eyes of Dr. Salazar-which is, perhaps, unlikely-I would humbly suggest that now is the time for him to beat the record of the great Marquis !

Another very interesting visit was paid to the English Institute, due to the energy and initiative of Dr. West, and now under the able direction of Mr. Leonard S. Downes, who represented the University of Glasgow at the celebrations. Amongst many other things, one was astonished to find here a library containing some English scientific journals and a goodly number of the most modern English books on chemistry and physics. In fact, the professors of chemistry told me that they were much indebted to the English Institute for keeping them in touch with the progress of British science. It is evident that the English Institute is very much alive and worthy of the strongest support. In the modern world the 'invisible' export of thought is an element of deep significance and importance. Britons in the past have been too apt to think that foreign nations are bound to assimilate the products of their thought and research by reason of some sort of inevitable predestination. This curious diffidence-or sublime trust in Providence-is not much good in the rough catch-as-catch-can of the thrusting modern world.

So, at last, came the train that bore us away from this city of learning, poetry and romance, where immortal Camões once lived and beautiful Inéz de Castro loved and suffered. With every student of Coimbra one could exclaim, "Não é Universidade como a minha!"

In conclusion, the British visitors to the Coimbra quatercentenary are deeply indebted to His Majesty's Embassy at Lisbon for invaluable help and much personal care and attention. Several of us, including the writer of this article, desire also to express our grateful thanks to Mr. Pell, the Minister of the United States in Portugal, and Mrs. Pell, for very delightful hospitality.

F. G. Donnan. 